\title{
JUNG AND THE PSYCHOLOGY OF RELIGION: A PRELIMINARY SKETCH
}

MATEI IAGHER

PHANÊS •VOLUME $1 ・ 2018 ・ P P . ~ 58-82$

https://doi.org/10.32724/phanes.2018.Iagher 


\begin{abstract}
This paper aims to position Jung's psychology of religion in the context of the development of the study of religion in the late nineteenth and early twentieth centuries. I argue that Jung's psychology of religion represents a synthesis between the 'science of religion' tradition, put forward by luminaries such as Max Müller and Cornelis Petrus Tiele, and the psychology of religion that Jung encountered in the works of his two intellectual masters, Théodore Flournoy and William James.
\end{abstract}

\title{
KEYWORDS
}

C.G. Jung, psychology of religion, science of religion, Max Müller, William James 


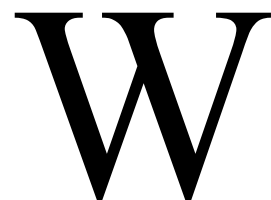

hile James Heisig's Imago Dei (1979) still remains the standard critical account of Jung's psychology of religion, Shamdasani's 'Is analytical psychology a religion? In statu nascendi' (1999) is, so far, the only attempt to work out the making of Jung's psychology of religion in a more general fashion. ${ }^{1}$ In what follows, I would like to expand on Shamdasani's remarks, and to offer a schematic account that will show how Jung's work fits into this wider intellectual tradition and into the tradition of the science of religion more broadly construed. ${ }^{2}$

The study of religion in the first decades of the twentieth century was in the process of being fundamentally reorganized by a group of psychologists calling themselves psychologists of religion. Devised mainly in the U.S., and championed by authors such as William James, Edwin Diller Starbuck, James Henry Leuba and G. Stanley Hall, the psychology of religion spread across the Atlantic, taking root in Germany, France, Switzerland, the United Kingdom, Italy, and reached as far as Eastern Europe. In 1927, a young Mircea Eliade was writing confidently that 'everyone knows the names of Ribot, Leuba and Janet', before proceeding to take these authors to task for equating mysticism with psychopathology (Eliade 2003:344).

Pathologising religious experiences was, however, not the norm among religious psychologists, and neither was their discipline always seen as simply an extension of psychology to a new realm. Rather, a good deal of researchers in the field sought to completely overhaul the science of religion, by turning the focus onto experiences (i.e. the experiences of religious practitioners), usually understood to be primarily emotional ones, and by turning the scientific gaze onto their own contemporaries. To quote one of the early luminaries of the discipline, the task was 'to catch at first hand the feelings of spirituality' (Starbuck 1937:223). This attempt to capture the lived experience of the homo religiosus was contrasted with the methods that had been at the centre of earlier attempts to form a science of religion. As George Coe, another psychologist of religion, wrote in 1900:

the history and science of religions rummaged museums of anthropology and dug about the roots of language in order to discover the earliest forms of religion: but to none of these

\footnotetext{
1 See also Ellenberger (1994), Wulff (1991), Lammers (1994), Shamdasani (1998; 2003; 2009), Liebscher (2018).

2 This paper is an emended version of a talk given at UCL in November 2016, as part of the first European Jung History Conference.
} 
was it revealed that the surest way to understand religion

is to observe its present manifestations (Coe 1900:12).

In addition to its emphasis on the 'present manifestation' of religion, the psychology of religion sought to refashion the science of religion on the basis of an affective definition of religion and by reference to a host of new concepts, such as 'conversion', 'mysticism', or the 'unconscious'. This affective understanding of religion had its starting point in the work of German Protestant theologian Friedrich Schleiermacher (1768-1834) (Mackintosh 1963:31-100; Jay 2005:88-102; Dole 2010; Gerrish 1984; Vial 2014).

In the early years of the nineteenth century, Schleiermacher set about trying to evade the strictures imposed by Kant(1724-1804) on the theoretical use of the faculty of reason. Kant presented a general account of the limits of knowledge in his classic Critique of Pure Reason (1781) and later took up the effects of that account on the knowledge of religion in Religion within the Boundaries of Mere Reason (1793) and in the posthumously published Lectures on Philosophical Theology (1830). As Kant made clear, for example in the latter text, one cannot really know anything about God, since God is not an object of experience. Strictly speaking, there can be no science of God, hence no theology, since 'I can have scientific knowledge only of what I myself experience' (Kant 1986:162). Therefore, belief is all that one can rely on in matters of religion, i.e. the postulate of God's existence, as a necessary adjunct for practical morality (Kant 1986:39). No science is required for this 'simple moral concept of God' (Kant 1986:167).

Schleiermacher's answer to this theoretical challenge was to claim that religion was not a thing of the mind, but of the heart. He first put forward this theory in a book addressed to his circle of Romantic friends in Berlin, and published anonymously in 1799 with the title On Religion: Speeches to its Cultured Despisers. The book was as much an exercise in rhetoric as it was a work of analysis. Its aim was to evoke a sense of the religious among its 'cultured despisers'. According to Schleiermacher, religion was neither metaphysics nor morality, even though one usually found it mixed together with these two fields. As he put it: 'Religion's essence is neither thinking nor acting, but intuition and feeling' (Schleiermarcher 1996:22). Religion was 'the sensibility and taste for the infinite', and the 'intuition of the universe' (Schleiermacher 1996:23-24). As intuitions were always individual, so was religion. Religious intuitions were self-contained and could not be reduced to something else. The intuition and the feeling of the infinite were fused together in the original moment of consciousness and 
Schleiermacher deplored the fact that the very act of analysis forced him to split them into rubrics. For him, it was impossible to fully translate the ineffability of religion into intellectual formulas without doing an injustice to its poetic originality. The dogmas and propositions of faith were only imperfect attempts to translate the richness of feeling and intuition into the alien language of reason (Schleiermacher 1996:48). As he put it: 'Every holy writing is merely a mausoleum of religion, a monument that a great spirit was there that no longer exists; for if it still lived and were active, why would it attach such great importance to the dead letter that only be a weak reproduction of it?' (Schleiermacher 1996:50).

Schleiermacher revisited these ideas in his work The Christian Faith, published in two parts in 1821 and 1822. The Faith was an innovative work that both developed Schleiermacher's earlier, affective based theory of religion and also outlined a radical new method in dogmatic theology. As in On Religion, Schleiermacher began by distinguishing piety from metaphysics and morality. Piety, for him, was 'but a modification of Feeling, or of immediate self-consciousness' (Schleiermacher 1928:5). In a further statement, he qualified this feeling by claiming that its essence was 'the consciousness of being absolutely dependent, or, which is the same thing, of being in relation to God' (Schleiermacher 1928:12). Since the essence of religion was a feeling, dogmas were only secondary constructions - they were, as he put it, only 'accounts of the religious affections set forth in speech' (Schleiermacher 1928:76). The task of theology was to systematise the dogmas in a certain community at a certain time and to check them against the statements of Christ in the Scriptures. As Wayne Proudfoot has noted, this procedure effectively made theology a thoroughly empirical discipline, since it no longer maintained that it was making claims about God or transcendence, but only about religious affections, or about the reflection of God in human consciousness (Proudfoot 1985:16; Vial 2014:36).

In the later years of the nineteenth century, the psychologists of religion rediscovered Schleiermacher's affective definition, in part, no doubt, because of a contextual similarity, one which E.D. Starbuck expressed as 'the dramatic battle [...] between Adam and the monkey' (Starbuck 1937:205). In less metaphorical terms, the 'battle' amounted to the strictures imposed on Christian belief not only by evolutionism, but also by higher criticism, materialistic reductionism, or by the famous 'ignoramus et ignorabimus' (we do not know and we will not know) put forward by German physiologist Emil du Bois-Reymond. ${ }^{3}$

${ }^{3}$ In the Zofingia lectures, given while he was a student, Jung took a critical stance towards du Bois-Reymond as well as towards materialistically minded 
For some, the fundamental affectivity of religion offered a way out of such quandaries. The theologian Otto Pfleiderer outlined this state of affairs in a series of lectures, published in English in 1907, describing the recent return to Schleiermacher as 'the New-romanticism of to-day'. For his part, he found the position unsatisfying, despite its popularity: 'Nowadays that seems a welcome way of escape for many, an easy peace-proposition in the bitter struggle between science and religion. Pity it is, that with this division of understanding and heart, the opposition is not reduced, but simply hidden and laid over' (Pfleiderer 1907:58).

\section{THE CLOTHED INFINITE}

Despite Pfleiderer's misgivings, a number of psychologists used their affective understanding of religion as part of a wider strategy of bringing 'science' and 'religion' together, of using 'science to buttress faith'(White 2009:3). In this goal, they differed little from the nineteenth century proponents of the 'science of religion', whose enterprise they sought to reform and supersede. In addition to having similar aims, the nineteenth century scientists of religion also drew on the same Liberal Protestant tradition, and a majority of them built psychological theories of religion, or pointed to the overwhelming importance of psychology for the understanding of their subject. The 'science of religion' enterprise included authors like Max Müller (1823-1900), the man who coined the expression 'science of religion,' Cornelis Petrus Tiele (1830-1902), his Dutch counterpart, the anthropologist Edward Burnett Tylor (18321917), Albert Réville (1826-1906) in France and a host of other lesser or greater theorists. In what follows I will outline two examples of the psychology of nineteenth century theorists of religion, namely those of Max Müller and C.P. Tiele. I shall highlight the psychological nature of the conceptions of these theorists, firstly, because the point has often been missed or glossed over in the history of the study of religion (Molendijk and Pels 1998; Sharpe 1986; Wheeler-Barclay 2010; Kippenberg 2002; Waardenburg 2017; Capps 1995). ${ }^{4}$

physiologists like Ludwig Büchner (Jung 1983:8).

4 The only notable exception is Evans-Pritchard (1965). Molendijk (2005) also contains references to the psychological discourse of some of the founders of the science of religion in the Netherlands, and especially Tiele. Concerning the latter he writes that 'it cannot be overlooked that within the emerging "science of religion", the psychology of religion came to the fore earlier than that [1905]. The work of C.P. Tiele illustrates this development very aptly' (Molendijk 2005: 218). 
Secondly, I will do so because it is unlikely that the psychology of religion would have spread so rapidly and gained so many enthusiastic adherents, had the public not already been primed by the psychological speculations of authors like Pfleiderer, E.B. Tylor, Müller, Tiele, Andrew Lang, or Ernest Renan. At the same time, in the case of Jung, the older psychology of these thinkers was married in creative ways with the new psychology. It is thus useful to outline two examples of this older psychology, particularly since one of these models is close to the one that Jung himself espoused in his work.

Like the psychologists of religion, Müller and Tiele were also interested in 'religious experience', though they sought to get to it via a detour through ancient texts and philological excavation. For Müller, such an approach made good Protestant sense: the more ancient the text, the more likely it was to contain the original experience, unsullied by the inexorable process of decay that attended any religious revelation (Müller 1868:24). Seen from this angle, Müller's edition of the Sacred Books of the East, which he began in 1876, can be seen as nothing short of a world scale reprisal of the role of Luther and other translators of the Bible. For Müller, psychology went straight to the heart of his account of religion. Starting with his Introduction to the Science of Religion (1873), Müller began defining religion as a mental faculty 'which, independent of, nay in spite of sense and reason, enables man to apprehend the Infinite under different names, and under varying disguises' (Müller 1882:13). By the late 1870 s, Müller gave up the notion of the faculty of faith in public. But he was only half-heartedly apologetic about his advocacy of such a faculty: in an 1882 reprint of the Introduction he kept the same language, and only inserted a footnote that explained that his use of the word 'faculty' merely meant that the mind had a possibility of doing something. He did not, however, feel that such terminology committed him to any specific view as to the ultimate nature of the mind (Müller 1882:16).

His colleague Tiele was critical of Müller's perceptual definition of religion, but agreed that the science of religion was tasked with uncovering the essential experience underscoring the variety of religious phenomena (Tiele 1899:228-231). As Tiele wrote in 1896, 'we study these phenomena - the conceptions and the observances of religion-in order to penetrate to what is concealed behind them' (Tiele 1897:37). Tiele intimated that 'the question as to the origin of religion is not of a historical or archaeological nature, but is purely psychological' (Tiele 1897:71). The science of religion, for him, had two components: a morphological one, which studied the forms (the morphai) of religion 
throughout history, and an ontological side which looked at what remained unchanged - in other words the essence, the psychological experience that created these various forms. He, thus, reckoned psychology to be a part of ontology. Religious experience, as he saw it (reformulating Müller and Schleiermacher), was ultimately a kind of incarnation of the Infinite: the Infinite, which he regarded as an innate form of thought, became actualised through the agencies of the imagination and of feeling and transformed spontaneously into a religious conception (Tiele 1899:121; 228-231).

Jung picked up part of his method from these nineteenth century comparativists like Müller and Tiele. While Jung's knowledge of Müller is easy to infer, because Jung referred to him in his published work, and also possessed some of his books in his personal library, as well as an almost complete set of the Sacred Books of the East, it is not clear whether Jung was in fact familiar with Tiele's theories. At most, I can infer that that he would have encountered passing references to him in a work which he possessed in his library, the 1905 Lehrbuch der Religionsgeschichte, edited by Chantepie de la Saussaye. Nevertheless, Jung's conception in Wandlungen und Symbole der Libido (WSL) (1911-1912) bears a striking resemblance to Tiele's theory. In the 1925 seminar, Jung recounted the famous dream that he had on his way back from America in 1909. In the dream, he found himself in a medieval house from which he descended first into a Gothic cellar, then into a Roman one beneath it. Finally, from a hole in the second cellar's floor he looked down into a dusty tomb, filled with fragments of pottery and ancient bones (Jung 2012:23). Jung said that this dream was the first intimation of the collective unconscious as well as the origin of WSL, which he began publishing in 1911 in the Jahrbuch für psychoanalytische und psychopathologische Forschungen, and then as a book in 1912. After his return from America, Jung began reading extensively on mythology, with the aim of finding a 'phylogenetic basis for the theory of neurosis' (Shamdasani 2003:214). That same year (1909), he quit his job at the Burghölzli, and moved into a new house that he had built for his family in Küsnacht.

The pretext for WSL was an article by a woman named Frank Miller, which appeared in the Archives de Psychologie in 1905 together with a short introduction by Flournoy (Miller 1906:36-51). Miss Miller was an American born in Alabama in 1878. She had travelled widely in Europe, and studied at several universities (including in Geneva), and had success as a popular lecturer in the U.S., where she spoke about and presented the garbs of countries like Russia, Greece, and Scandinavia (Shamdasani 1990; Serina 2016). Flournoy presented her as possessed of a hypersensitive, almost 
mediumistic temperament, coupled, however, with a critical acumen and a lively intelligence. He did not doubt that, had she lacked in introspection and self-criticism, she would have become a successful purveyor of subliminal romances, much like Hélène Smith, the subject of Flournoy's book From India to the Planet Mars (Flournoy 1906:36-38). Miss Miller was, as she herself noted, completely opposed to spiritualist interpretations. The point of her article was precisely to offer a naturalistic explanation of some personal episodes of unconscious or semi-conscious reverie and lyrical genesis, with the aim of "dispersing the superstition of so-called "spirits" (Miller 1906:48). She used the explanatory paradigm of cryptomnesia, set out by Flournoy in From India to the planet Mars, and traced back her 'fantasies' to forgotten or half-remembered incidents in her life.

Jung did not take Miller's explanations at face value, quite likely because he thought them to be insufficient, and instead proceeded to treat them somewhat like free associations. His argument in WSL started with a distinction between fantasy and directed thinking. $\mathrm{He}$ claimed that directed thinking was adapted to reality and objective, whereas fantasy thinking was subjective, nebulous, and dreamy. Fantasy thinking was a survival from ages past, when mythology held humans in its sway (Jung 1916:24). In what was a common anthropological move, he regarded fantasy thinking as the primary mode of thinking for children and primitive peoples, and also equated it with the kind of thinking that was common in dreams. In children's fantasies, one had the proof that, psychologically, ontogeny repeated phylogeny. Such fantasy thinking was, furthermore, the basis for all mythology and religion:

One can say, that should it happen that all traditions in the world were cut off with a single blow, then with the succeeding generation, the whole mythology and history of religion would start over again. Only a few individuals succeed in throwing off mythology in a time of a certain intellectual supremacy - the mass never frees itself. (Jung 1916:30).

\footnotetext{
${ }^{5}$ In his review of Jung's WSL, Flournoy referred to her procedure as being a “"psychoanalysis” avant la lettre'. See Théodore Flournoy, review of C.G. Jung, Wandlungen und Symbole der Libido: Beiträge für Entwicklungsgeschichte des Denkens, Archives de psychologie 50, 13 (1913):195.
} 
As this quote suggests, religion and mythology were genetically related (if not identical), they were psychically ingrained, and they were to be overcome (at least by those who were gifted enough to rise above the mass). This negative evaluation of religion was implicit in the conception that religion was the result of a lower form of thinking. One became religious (or mythological) as a result of fatigue, of an abaissement du niveau mental, whose correlative was a loss of what Janet called 'the function of the real' (Jung 1916:142-153). It was the extent of this loss of the function of reality in schizophrenia that convinced Jung that the libido was not purely sexual, but more like a vital energy or Schopenhauerian Will. As he put it, with regard to dementia praecox:

The function of reality is lacking to such a degree that even the motive power must be encroached upon in the loss. The sexual character of this must be disputed absolutely, for reality is not understood to be a sexual function (Jung 1916:143).

The self-deepening of psychotics into a world of fantasy led to a 'loosening up of the historical layers of the unconscious.' (Jung to Freud, 12 June 1911, in McGuire 1994:427). As such:

it may be concluded that the soul possesses in some degree historical strata, the oldest stratum of which would correspond to the unconscious. The result of that must be that an introversion occurring later in life, according to the Freudian teaching, seizes upon regressive infantile reminiscences taken from the individual past. That first points out the way; then, with stronger introversion and regression (strong repression, introversion psychoses), there come to light pronounced traits of an archaic mental kind, which, under certain circumstances, might go as far as the reecho of a once manifest, archaic mental product (Jung 1916:37).

Thus, the fantasies that were triggered by such introversions revealed not only personal or infantile memories, but memories of the race. A case in point was the Solar Phallus Man, who hallucinated the ancient myth of a sunphallus that could also be found almost identically in the Mithraic liturgy (Jung 1916: 108-109). Jung expanded Flournoy's cryptomnesia paradigm so as to include such ancient memories. As Shamdasani has argued, one could call this method a 'phylo-cryptomnesia' (Shamdasani 2003:218). In later editions of Wandlungen and Symbole der Libido, Jung would 
retrospectively supply a diagnosis for Miss Miller that would more closely fit this model, turning her into a nascent schizophrenic (Shamdasani 1990:27).

Jung's project in WSL seems to have been, in part at least, a synthesis between the comparative religion project of people like Müller and Tiele and the religious psychology of James, Flournoy and Janet. There is in fact a striking similarity between Jung's conception in WSL and that of Tiele. To recapitulate, Tiele claimed that the study of myths and symbols provided a window into the embryology of religion: a way of seeing how early man had used the faculty of the imagination to give concrete form to a diffuse Infinite, lurking in one's unconscious depths. Mutatis mutandis, Jung argued the exact same thing: one only has to replace 'imagination' with 'fantasy thinking' and 'the Infinite' with the equally protean libido. Contrary to Tiele, however, Jung claimed that this imaginative process also took place among his contemporaries - indeed that every person carried within them both the libido and its typical forms. A loss of psychological tension (as in a psychosis, an introversion, or a dream) could show that this mythologizing capability had not been lost. This argument served as the justification for why Jung studied Ms. Miller's religious fantasies side by side with the ancient myths and symbols of Greece, India, or Egypt.

Jung carried themodel thatheoutlinedin WSLintohis latercomparative work, which took off in the 1920s, after he finished with The Red Book and after he outlined the process of individuation. In this later comparative project, Jung attempted to find parallels to individuation in the world's religious traditions: yoga, Buddhism, alchemy, The Spiritual Exercises of Ignatius of Loyola (Jung 1952, 1960). One can consider this project as an update on the Müller-Tiele model: having established what the psychological experience was (i.e. individuation), he began searching for iterations of it in The Sacred Books of the East and in European alchemical texts.

\section{EFFECTING 'CONVERSIONS'}

As mentioned above, the psychology of religion constituted itself in opposition to the earlier science of religion. In other words, much like the aforementioned quote from Coe stipulated, the task was no longer to look at anthropological accounts or at ancient texts, but rather at contemporary experiences - and then to try to tease psychological meaning out of them. However, at least in the U.S., the question that the religious psychologists asked was in a sense the same question that the comparative religionists and anthropologists had asked before: what is 
the origin of religion? (Masuzawa 1994). The question was, however, no longer asked in the historical sense (how did the primitives get religion?), but rather in the sense of: how does contemporary man get religion? The psychologists of religion called this topic 'conversion'.

The psychology of conversion was outlined in a number of foundational texts, such as James Henry Leuba's 'A Study in the Psychology of Religious Phenomena' (1896), E.D. Starbuck's The Psychology of Religion (1899), William James' Varieties of Religious Experience (1902), and G. Stanley Hall's Adolescence (1904). Though there was some European contribution to the discussion (Allier: 1925), conversion was without a doubt the preserve of the Americans. Jung was familiar with at least some of the debates around conversion from William James' Varieties.

Conversion for the American psychologists was not so much about adopting a different 'religion' as it was about the psychological development of a new centre of personality. The process was usually described as comprising going through an inner struggle with one's own sinfulness and potential damnation, which was often (sooner or later as the case may be) resolved into a state wherein earlier contradictions seemed resolved, such that joy and well-being replaced despair and doubt (Starbuck 1911; James 2002; Coe 1900; Leuba 1896). The whole discussion was embedded in a Protestant practice and used the vocabulary of Protestantism. The scientific presumption of the psychology of religion came from its use of questionnaires, which aimed to record the experience raw, before it was used for drawing conclusions. But then again, the majority of respondents were also Protestants, though the whole process was assumed to be universal - at least until 1920, when James Bissett Pratt exposed the whole enterprise as little more than a translation of theological terms into the language of psychology (Pratt 1920:154). As there were seemingly infinite variations to the conversion process, discussion among the psychologists of religion raged on about how to describe the process, what factors had the upper hand, and whether, ultimately, the whole process was so individual that it remained mysterious and defied all rational description - as both James and Starbuck suggested (James 2002:162; Starbuck [undated manuscript]:1). Be that as it may, there was a significant degree of consensus that the process of conversion corresponded in general to the normal process of adolescent growth.

For some of the psychologists of religion, conversion served as a way of 'naturalizing' religion, of making it an indelible part of the psychology and even physiology of the individual. As stated above, such a procedure took religion out of the ambit of critique and into the realm of the inevitable, 
offering a solution to the perceived science vs. religion debate. For some psychologists, such as William James, religion served a special function. In the Varieties of Religious Experience, James argued that this function was to heal the 'divided self', James' preferred phrase for a constitutional imbalance or existential rift, whose healing sometimes came only through a conversion. As James put it, this existential rift 'reduced to its simplest terms, is a sense that there is something wrong about us as we naturally stand'. The value of religion came from that fact that, through it, one received 'sthenic affection' which provided an exit from the drama of existence through the instrument of a connection with 'the higher powers' (James 2002: 390-92).

Both James' 'special function', as well as the more usual 'naturalisation' of religion that was attempted by others, created a problem for the psychology of religion, which found itself trapped in an insoluble paradox. The paradox is that the very attempt to naturalise religionto make it an inextricable part of the psychology or even physiology of the individual - ends up dooming both 'religion' and the psychology of religion with it. The problem is this: if one argues that conversion is a normal process of adolescent growth, which happens with or without religion, religion becomes superfluous. The object of the psychology of religion has been dissolved in the very process of analysing it. And, in fact, the psychology of religion is dissolved as well, because it no longer deals with anything specifically 'religious', but simply with psychological processes as such. The corollary is that one also now has a psychological and hence 'scientific' description of what before was described imperfectly, or at least unscientifically, by religion. Therefore, this is a further reason to scrap religion and to proclaim psychology as the new theology, the new religion - or as the only legitimate form of speculation on these states of transformation labelled conversion. As James Leuba wrote in his conversion study, 'when the division between metaphysics and science has been fully recognized in Religion, the church will take cognizance of facts only, and leave to independent specialists the post-experiential speculations' (Leuba 1896:320). Exactly the same problem appears with James: if religion is that which heals the divided self, what is it about religion that has this healing function? Would it not be possible to achieve the same results, through some other means, such as psychotherapy?

Jung answered this question in the positive, and he also borrowed James' terms to describe the goal of psychotherapy as a healing of the divided self (Jung 1932, CW11: §488-538). Furthermore, at least two of the essential elements of his psychology of religion can be considered as reformulations of methodological procedures borrowed from previous 
psychologists of religion-most notably William James and Théodore Flournoy, the two psychologists of religion whose work he highly prized. A third methodological procedure, namely the separation between 'religious experience' and its intellectual or dogmatic formulation was probably reinforced by Jung's reading of James and Flournoy, though its deeper source was Friedrich Schleiermacher. Jung belatedly acknowledged his indebtedness to Schleiermacher in a late letter written to Henry Corbin in 1953:

Your intuition is astounding: Schleiermacher really is one of my spiritual ancestors. He even baptized my grandfatherborn a Catholic - who by then was a doctor. This grandfather became a great friend of the theologian de Wette, who had connections of his own with Schleiermacher. The vast, esoteric, and individual spirit of Schleiermacher was a part of the intellectual atmosphere of my father's family. I never studied him, but unconsciously he was for me a spiritus rector (Jung to Corbin, 4 May 1953, in Adler and Jaffé 1991: 115). ${ }^{6}$

Jung acknowledged the role played by Flournoy and James in his intellectual formation in the unpublished protocols of Memories, Dreams, Reflections. Together with his friend James, Flournoy was one of the founding fathers of the psychology of religion (Iagher 2014). Even before meeting him, Jung had offered to translate his From India to the Planet Mars into German. He also visited him in Geneva during his time at the Bürgholzli. Jung also later perused Flournoy's account of a case of a contemporary Protestant mystic (Une mystique moderne), of which he possessed two copies in his personal library. In the protocols, Jung claimed that Flournoy was an intellectual mentor for him, at a time when he felt that he was too young to strike out on his own. He also thought that Flournoy shared his interests (e.g. in psychical research and religion) and general way of looking at things, at a time when no one else did. He stated that he had borrowed from Flournoy the notion of creative imagination, that Flournoy had taught him how to immerse himself in a case, and that

6 It is quite likely that Jung also had a second hand knowledge of Schleiermacher, which he could have derived, for example, from Otto Pfleiderer's Die Religion, ihr Wesen und ihre Geschichte, auf Grund des gegenwärtigen Standes der philosophischen und der historischen Wissenschaft, 2. vols. (Leipzig: Fues Verlag, 1869), which he posessed in his personal library. As Ellenberger points out, Schleiermacher had his own notion of individuation, though it's unclear whether Jung was aware of this (Ellenberger 1994: 729). 
his Genevan mentor had a wider, more objective outlook that helped him overcome the one-sidedness of Freud. Jung also had a good rapport with James, whom he remembered to have met twice (at Clark in 1909 and also in 1910). Jung claimed that James and him understood each other excellently on the role that religious factors had in the psyche. At the same time, Jung also stated that he found James to be a bit dry, a bit too much of a philosopher and that it was Flournoy that was emotionally closer to him.

Regardless of the depth of his personal feelings towards the two men, Jung borrowed both concepts as well as some of his methodology from them. Firstly, in his psychology of religion Jung reformulated the question about the origin of religion into a question about the religion-making process. Between 1913 and 1928, Jung was engaged in an experiment that resulted in the production of Liber Novus and in the articulation of a cosmology and a soteriology. According to his own account in Liber Novus, the experience also comprised a divine revelation. In a cryptic letter that he wrote to Adolf Keller in 1915, Jung hinted that the process he was going through would lead to a state of 'mystical development and unification':

1st Stage: introversion: separation of the individual from society. This happens not without misunderstanding, because of a too strong sticking together. Hostility and hatred = war. 2nd Stage: libido in the mother: resurrection of the archaic $=$ psychosis. Unleashing of the highest and the deepest. An almost anarchic condition, at any rate dissolution of society in the highest degree (dismemberment motif). 3rd Stage: hatching out. A mystical development and unification, of which I can say myself only too little, for I can only intuit it rather than think it. For we have barely experienced it so far. The dismemberment of the old is not yet accomplished. The isolation will become terrible. The beginning is given in the national isolation. (Jehle-Wildberger 2014:45).

In 1916, he gave a talk to the Association for Analytical Psychology, in which he further translated this process into the language of psychology, outlining what he called the process of individuation (Jung 1920: 444474). Starting in the 1920s, Jung began looking for parallels to the individuation process in the world's religions. The psychology of the religion-making process that Jung articulated in the aftermath of Liber Novus can be seen as a synthesis between the two questions of origins 
from the comparative religionists and the religious psychologists: like the psychologists, he started from an experience-only in this case, it was his own-and like Müller and Tiele, he tried to compare this experience with what he could glean from the world's traditions.

Secondly, much like some of the religious psychologists before him, Jung attempted to 'naturalise' religion - to make it an indelible part of human nature. This is evident from statements to the effect that the psyche has a religious function. Jung described this function (that of symbol formation), in Psychological Types (1921): 'wherever we can observe a religion at its birth, we see how even the figures of his doctrine flow into the founder as revelations, i.e. as concretisations of his unconscious phantasy' (Jung 1946:70). If such concretisations were generally accepted (as was the case with Christ and other religious founders), they turned into 'stereotyped symbolical ideas' - which was Jung's way of referring to dogmas. In his view, religions offered such 'stereotyped symbolical ideas' that expressed 'the stages of unconscious processes in a typical and universally binding form' (Jung 1946:70). The question here is whether Jung's psychological description was in fact any different from such 'stereotyped symbolical ideas' that expressed 'the stages of unconscious processes in a typical and universally binding form'. The problem once again is that once you make religion an integral part of the psyche, and you have a scientific psychology that is supposed to describe that psyche in its totality, at that point psychology becomes a direct competitor to any traditional, or, so to speak, 'religious' description - because it is scientific, and hence more precise. Now Jung says as much in Psychological Types, when he writes that:

Our science is also a language of metaphor, but from the practical standpoint it succeeds better than the old mythological hypothesis, which expresses itself by concrete presentations, instead of, as we do, by conceptions. (Jung 1946:314).

This solution may not have been sufficient, as a year later Jung recorded a conversation between the 'I' and his 'soul,' in which the latter pressed him to make the revelation public:

[I]: But what is my calling?

[Soul]: The new religion and its proclamation.

[I]: Oh God, how should I do this?

[Soul]: Do not be of such little faith. No one knows it as you do. There is no one whocould say it as well as you could. 
[I]: But who knows, if you are not lying?

[Soul]: Ask yourself if I am lying. I speak the truth

(Jung, RB:211).

As Shamdasani has noted, Jung recoiled from this proposal and sought instead to understand the religion-making process (Shamdasani 2009:62). In an after dinner speech given in New York in 1936, Jung stated: 'This sounds like a religion, but it is not so. I am speaking just as a philosopher. People sometimes call me a religious leader. I am not that. I have no message, no mission; I attempt only to understand.' (Jung 1993:98). Jung's statement was predicated on the notion that he could separate the experience from its dogmatic elaboration. In the Terry lectures which Jung had just finished giving at Yale in 1937, the distinction Jung used was between the 'numinosum', a term he had borrowed from Rudolf Otto, and the 'creed.'(Jung 1937, CW 11: §§6-11). The numinosum represented the defining aspect of religious experience, and creeds were 'codified and dogmatised forms of original religious experience.' (Jung 1937, CW 11: §10). This distinction was a recasting of an earlier one he had made in 1923, between the the 'fire' and the 'form'.

In 1923, Jung held a seminar in Polzeath, on the Cornish coast. The seminar was Jung's first major statement in public about the historical significance of Christianity. In Polzeath, he defined religion as 'the formulation of a universal attitude' (Jung 1923:71). The universal attitude was conditioned by certain dogmas, and in order to be universal it had to be assumed unconditionally as well. Christianity, Jung claimed, was no longer a valid formulation of this universal or impersonal attitude. Christianity had only truly been the universal attitude during the Middle Ages. As he put it in a striking sentence: 'The real Christianity was Medieval' (Jung 1923:74). The Christian impersonal attitude had gone to pieces because of the Renaissance and the Reformation. As opposed to the Middle Ages, when there was a general sense of connectedness amongst the people of the known world (the same religion, the same science, the same language), contemporary people lived in utter separation from each other. They lacked 'collective representations', and had only tribal or at best national representations, as had been shown by the recent war (Jung 1923:68).

People had become unconscious of a general symbol. This lack had resulted in a constellation of the collective unconscious. A new symbol could, nevertheless, be created: 'creative fantasy could produce a religion in ourselves, because it can produce the symbol by which we live' (Jung 1923:89). As he put it, 'the thing that still works in us may 
be a religious attitude, but it is not nowadays naturally Christian and need not be Christian everywhere' (Jung 1923:74). In one passage, Jung compared analytical psychology and Christianity. Both of these had a spiritual fire in them, and both sought a form (Jung 1923:79). He said: 'I myself am always seeking form. Well, if we find a form that satisfies our expectations, we are done for.' (Jung 1923:82). According to him, the form, or the church, had taken the life out of Christianity, and Jung wondered if the same fate awaited his movement. He implied that the loss of the fire by Christianity happened because the Church had produced four psychological exclusions (or repressions): 1) of nature; 2) of the animal; 3) of the inferior man; 4) of creative fantasy and freedom (Jung 1923:75-77). By contrast, analytical psychology could rekindle the fire by taking these psychological issues into account (Jung 1923:89).

According to these statements, analytical psychology did come close to a religion, but Jung wanted to keep it from turning into a church. As Shamdasani has argued, it was in the form of psychotherapy that Jung's psychology came closest to a religion, because the role of psychotherapy was to facilitate religious experiences. As Jung wrote in 1943, psychotherapy was a religion in statu nascendi-a religion in the process of being born - the idea being not that it should be born, but that it should remain in a nascent state (Jung 1943, CW 16: §181).

As already hinted at above, Jung understood the healing that came out of the psychotherapeutic encounter as similar to the way in which conversion functioned in William James' account in the Varieties of Religious Experience. For James, the value of conversion came from its ability to heal the 'divided self'. In 1932, Jung gave a paper at a pastors' conference in Strasbourg on the relationship between psychotherapy and the cure of souls. In it, Jung put forward an argument for why the Protestant Seelsorger needed to take up the study of analytical psychology (Jung 1932, CW 11: §§488-538). He argued that neuroses were at bottom problems of a loss of meaning. They were problems that required a philosophical, spiritual or religious solution, not a medical and certainly not a reductionist one. Ultimately, they required an experiential solution, which Jung compared with Saul's conversion on the road to Damascus. In a Jamesian manner, Jung described neurosis as 'an inner cleavage, a division (Entzweiung) within oneself' which could only be healed by religion or in a religious fashion (Jung 1932, CW 11: $\S \S 522-531) .^{7}$ As opposed to

\footnotetext{
7 Jung probably did not read James' Varieties of Religious Experience until after 1919. He had two copies of the book in his library: an English edition from 1919 and a French translation from 1931.
} 
James, however, he did not simply record this, but claimed that he could bring it about. Psychotherapy was thus the answer to the 'divided self.'

\section{CONCLUSION}

The argument presented here has sought to highlight several elements that Jung borrowed from the psychology of religion that came before him, and from the science of religion articulated by scholars like Max Müller and C.P. Tiele. Firstly, Jung's central conceptual framework in his psychology of religion was that of the Liberal Protestant theological tradition, whose founding father was Friedrich Schleiermacher. The defining feature of this framework was the sharp separation between 'religious experience' and its intellectual translation into dogmas, or between the 'fire' and the 'form', to use Jung's language in the Polzeath seminars. Furthermore, Jung did not seem to be bothered by the fact that this model was ultimately Christian, for, despite his forays into other traditions, he never considered himself to be out of the fold. As he told the pastors in Strasbourg, he was 'on the extreme left wing in the parliament of Protestant opinion' (Jung 1932, CW 11:§537). Secondly, I have argued that Jung's comparative study of the individuation process was a synthesis between psychology of religion and the science of religion outlined by theorists such as Müller and Tiele. These latter theorists speculatively tried to understand the origin of religion in a psychological fashion. Having arrived at what they thought was the fundamental experience of religion, they sought out the ways in which this experience was embodied in the world's traditions. The psychologists of religion brought the question concerning the origin of religion into the present, searching out the ways in which the contemporary individual 'got religion' through conversion. Jung combined these into a practice whereby, starting from his own experience, as recorded in Liber Novus, he outlined a universal process of individuation, for which he sought parallels in the world's traditions.

Thirdly, I have tried to show how Jung's wrestling with the notion of whether his psychology was a religion or not was rooted in the central paradox of the psychology of religion. The idea that religion was an experience that could be separated from its dogmatic or traditional formulation resulted in a situation where either religion was dissolved into psychology, or in one in which, regardless of the intrinsic value of that experience, theological formulations were deemed insufficient and non-scientific, particularly when compared to psychological ones. For Jung, this problem was compounded by the expectation that the analytical encounter would 
itself be able to foster such religious experiences. As Jung furthermore stipulated, such experiences bore the hallmarks of the conversion narrative outlined by William James: they were experiences which healed the divided self. For all intents and purposes, Jung's psychology performed the same function as religion. What Jung did not want was for his own psychology to be turned into a creed. In part at least, this came from an understanding that his own categories were makeshift (Hillman and Shamdasani 2013:73). The experience of the numinous overrode any interpretation.

New Europe College

matei_iagher@yahoo.com

\section{REFERENCES}

Allier, Raoul. 1925. La Psychologie de la conversion chez les peoples non-civilisés. 2 vols. Paris: Payot.

Capps, Walter H. 1995. Religious Studies: The Making of a Discipline. Minneapolis: Fortress Press.

Chantepie de la Saussaye, P.D. (editor). 1905. Lehrbuch der Religionsgeschichte. 3rd edition. Tübingen: J.C.B. Mohr.

Coe, George A. 1900. The Spiritual Life: Studies in the Science of Religion. New York: Eaton \& Mains.

Conrad Lammers, Ann.1994. In God's Shadow: The Collaboration of Victor White and C.G. Jung. New York and Mahwah, N.J.: Paulist Press.

Dole, Andrew C. 2010. Schleiermacher on Religion and the Natural Order. Oxford: Oxford University Press.

Evans-Pritchard, E.E. (1965). Theories of Primitive Religion. Oxford: Clarendon Press.

Ellenberger, Henri F. 1994. The Discovery of the Unconscious: The History and Evolution of Dynamic Psychiatry. London: Fontana Press.

Eliade, Mircea. 2003. Itinerariu Spiritual: Scrieri de tinerețe. Ed. Mircea Handoca. București: Humanitas.

Flournoy, Théodore. 1915. 'Une mystique moderne (documents pour 
la psychologie religieuse)'. Archives de psychologie 15: 1-224.

Freud, Sigmund and Jung, C.G. 1994. The Freud/Jung Letters:

The Correspondence between Sigmund Freud and C.G. Jung. Edited by William McGuire, translated by Ralph Manheim and R.F.C. Hull. Princeton: Princeton University Press.

Gerrish, B.A. 1984. A Prince of the Church: Schleiermacher and the Beginnings of Modern Theology. Philadelphia: Fortress Press.

Heisig, James W. 1979. Imago Dei: A Study of C.G. Jung's Psychology of Religion. London: Associated University Press.

Hall, G. Stanley. 1921 [1904]. Adolescence: Its Psychology and its Relations to Physiology, Anthropology, Sociology, Sex, Crime, Religion and Education. 2 vols. New York: D. Appleton and Company.

Hillman, James and Shamdasani, Sonu. 2013. Lament of the Dead: Psychology after Jung's Red Book. London: W.W. Norton \& Co.

Iagher, Matei. 2014. 'From America to the Planet Florissant: Théodore Flournoy and the Psychology of Religious Experience'. Piper: International Psychology, Practice and Research 5:1-24.

James, William. 2002 [1902]. Varieties of Religions Experience. A study in Human Nature. London: Routledge.

Jay, Martin. 2005. Songs of Experience: Modern American and European Variations on a Universal Theme. Berkley: University of California Press.

Jehle-Wildberger, Marianne. 2014. C.G. Jung und Adolf Keller. Über Theologie und Psychologie: Briefe und Gespräche. Zürich: Theologischer Verlag Zürich.

Jung, C.G. 1916. Psychology of the Unconscious: A Study of the Transformations and Symbolisms of the Libido, A Contribution to the History of the Evolution of Thought. trans. Beatrice M. Hinkle. New York: Moffat, Yard and Co. 1920. Collected Papers on Analytical Psychology. Edited and trans. Constance E. Long, 2nd edition. London: Baillière, Tindall and Cox.

1923. 'Notes on the Seminar in Analytical Psychology. Conducted by Dr. C.G. Jung. Polzeath, England, July 14 - July 27, 1923. Arranged by Members of the Class'. [unpublished]. 
—. [1921] 1946. Psychological Types or The Psychology of Individuation. trans. H.G. Baynes. 1923. Reprint, London: Kegan Paul, Trench, Trubner \& Co.

- [1932]. Psychotherapists or the Clergy. Collected Works of C.G.Jung, vol. 11, §§488-538.

- [1937]. Psychology and Religion. Collected Works of C.G.Jung, vol. 11, §§1-168. 1952. Modern Psychology. The Process of Individuation: vol. 3 Eastern Texts/vol. 4 Exercitia Spiritualia of St. Ignatius of Loyola. Notes on Lectures given at the Eidgenössische Technische Hochschule, Zürich, October 1938-March 1940. 2nd Edition. n.p.: n.p.

- 1960. Modern Psychology. Alchemy. The Process of Individuation: vol. 1 and 2. Notes on Lectures given at the Eidgenössische Technische Hochschule, Zürich, November 1940- July 1941. n.p: n.p. 1991. Letters, vol.2: 1951-1961. Edited by Gerhard Adler and Aniela Jaffé. Trans. R.F.C. Hull. London: Routledge and Kegan Paul.

. 1993. 'Is analytical psychology a religion', in C.G. Jung Speaking: Interviews and Encounters. Edited by William McGuire and R.F.C. Hull. 3rd. edition. Princeton: Princeton University Press. 1983. The Zofingia Lectures. Trans. Jan van Heurck. London: Routledge \& Kegan Paul. 2009. The Red Book: Liber Novus. Edited and with an Introduction by Sonu Shamdasani. Trans. by Mark Kyburz, John Peck, and Sonu Shamdasani. London: W.W. Norton \& Company.

Kant, Immanuel. 1986. Lectures on Philosophical Theology. Trans. Allen W. Wood and Gertrude M. Clark. Ithaca, NY: Cornell University Press. 1998. Critique of Pure Reason. Trans. Paul Guyer and Allen W. Wood. Cambridge: Cambridge University Press.

- 1998. Religion within the Boundaries of Mere Reason And Other Writings. Trans. Allen Wood and George di Giovanni. Cambridge: Cambridge University Press. 1986. Lectures on Philosophical Theology. Trans. Allen W. Wood and Gertrude M. Clark. Ithaca, NY: Cornell University Press.

Kippenberg, Hans G. 2002. Discovering Religious History in the Modern Age. Trans. by Barbara Harshav. Princeton: Princeton University Press. 
Leuba, James H. 1896. 'A Study in the Psychology of Religious Phenomena'. The American Journal of Psychology VII , 3: 309-85.

Liebscher, Martin. 2018. 'C.G. Jung and the Berneuchen Movement: Meditation and Active Imagination in Jungian Psychotherapy and Protestant Spiritual Practice in the 1930s'. In Mererid Puw Davies and Sonu Shamdasani (eds.). Medical in/humanities in German. [in press].

Mackintosh, Hugh Ross. 1963. Types of Modern Theology: Schleiermacher to Barth. London: Nisbet.

Masuzawa, Tomoko. 1994. In Search of Dreamtime: The Quest for the Origin of Religion. Chicago: University of Chicago Press.

Miller, Frank. 1905. 'Quelques faits d'imagination créatrice. Avec un introduction par M. Th. Flournoy'. Archives de psychologie V : 36-51.

Molendijk, Arie L. and Pels, Peter. (editors). 1998. Religion in the Making: The Emergence of The Sciences of Religion. Leiden: Brill.

Molendijk, Arie L. 2005. The Emergence of the Science of Religion in the Netherlands. Leiden: Brill.

Müller, Max. 1868. Chips from a German Workshop: Essays on the Science of Religion. 2nd edition. vol. 1. London: Longmans, Green, and Co.

1882. Introduction to the Science of Religion: Four Lectures Delivered at the Royal Institute in February and May 1870. Longmans, Green, and Co.

Pratt, James Bissett. 1907. The Psychology of Religious Belief. New York: Macmillan.

Protocols of the interviews conducted by Aniela Jaffé with C.G. Jung for Memories, Dreams, Reflections. Library of Congress, Washington, DC.

Proudfoot, Wayne. 1985. Religious Experience. Los Angeles: University of California Press.

Schleiermacher, Friedrich Daniel Ernst. 1928. The Christian Faith. Trans. H.R. Mackintosh and J.S. Stewart. Ediburgh: T\&T Clark.

-1996. On Religion: Speeches to its Cultured Despisers. Trans. Richard Crouter. Cambridge: Cambridge University Press.

Serina, Florent. 2016. 'Le cas Miss Miller, de Théodore Flournoy à C.G. Jung. Introduction à «Quelques faits d'imagination créatrice subconsciente» de Frank Miller'. Cahiers jungiens de psychanalyse 2 
(144):11-28.

Shamdasani, Sonu. 1990. 'A Woman Called Frank'. Spring 50: 26-56.

1998. Cult Fictions: C.G. Jung and the Founding of Analytical Psychology. London: Routledge.

1999. 'Is Analytical Psychology a Religion? In Statu Nascendi'. Journal of Analytical Psychology 44: 539-545.

- 2003. Jung and the Making of Modern Psychology: The Dream of a Science. Cambridge: Cambridge University Press.

Sharpe, Eric J. 1986. Comparative Religion: A History. 2nd edition. La Salle, Illinois: Open Court.

Starbuck, Edwin Diller. n.d. 'Conversion'. Edwin Diller Starbuck Papers, University of Southern California.

- 1911 [1899]. Psychology of Religion: An Empirical Study of the Growth of Religious Consciousness. 3rd edition. London: The Walter Scott Publishing Co.

1937. 'Religion's Use of Me', in Vergilius Ferm (ed.). Religious in Transition. London: George Allen\& Unwind Ltd.

Pfleiderer, Otto. 1907. Religion and Historic Faiths. New York: B. W. Huebsch.

Tiele, C.P. 1897. Elements of the Science of Religion, Part I. Morphological: Being The Gifford Lectures Delivered Before the University of Edinburgh in 1896. London: William Blackwood and Sons.

-1899. Elements of the Science of Religion, Part II: Ontological: Being The Gifford Lectures Delivered Before the University of Edinburgh in 1898. London: William Blackwood and Sons.

Vial, Theodore. 2014. 'Friedrich Schleiermacher'. In Nineteenth-Century Philosophy of Religion. Edited by Graham Oppy and N.N. Trakakis Volume 4 of The History of Western Philosophy of Religion. London: Routledge.

Waardenburg, Jacques. 2017. Classical Approaches to the Study of Religion: Aims, Methods, and Theories of Research. Introduction and Anthology. Berlin: De Gruyter.

Wheeler-Barclay, Marjorie. 2010. The Science of Religion in Britain, 1860-1915. London: University of Virginia Press. 
White, Christopher G. 2009. Unsettled Minds: Psychology and the American Search for Spiritual Assurance, 1830-1940. Berkley: University of California Press.

Wulff, David. 1991. Psychology of Religion: Classic \& Contemporary Views. New York: John Wiley \& Sons. 